even in education. Meanwhile, there is danger that, apart from their destructive effect upon certain habits and institutions that make for stability and coherence in our social life, those influences may set the minds of men and women in ways which make it even more difficult to achieve the constructive possibilities. To counter that, it is the more important that the utmost use should be made of the opportunities which exist in broadcasting at present, either through the Third Programme or other programmes, of creating, possibly in co-operation with the Press and other means, an informed public opinion which is essential if policy is to be formed and action taken in fields such as defence, education, health or trade. To that end informed public discussion of current issues is a vital contribution.

\section{THE LIFE OF DARWIN}

The Autobiography of Charles Darwin, 1809-1882 Edited by Nora Barlow. Pp. $253+4$ plates. (London : William Collins, Sons and Co., Ltd., 1958.) 16s. net.

T ADY BARLOW keeps adding to our debt of 1 gratitude for her untiring care in editing or de-editing the literary remains of her illustrious grandfather.

It is good to have Charles Darwin's original biographical sketch as it was written and left for the information of his children and grandchildren "with original omissions restored". His grand-daughter's notes are helpful and informative, and do not trouble or interrupt the narrative.

About half the book is, however, devoted to new material. There are two appendixes, one of eighteen pages "On Charles Darwin and his grandfather Dr. Erasmus Darwin", and one of more than fifty entitled "The Darwin--Butler Controversy". The six notes which complete the volume are of personal and bibliographical interest, and take only twenty six pages.

The relationship between Charles Darwin's evolutionary doctrine and that of Erasmus Darwin is treated here in terms of the theories, if that is not too strong a word, held by Charles on the subject of scientific inference. I believe this point of view does less than justice to his grandfather, who wrote in the tradition of didactic poetry, and was, to the taste of his century, one of the greatest of poets. I do not understand that this fact should be ignored merely because, eighty years later, the function of poetry in contemporary literature had changed; and people like Coleridge had written spitefully.

The charge that Charles plagiarized his grandfather's work, and took credit for his ideas, was indeed nothing but a malicious falsification due, I suppose, to Samuel Butler relying on the public's lack of direct familiarity with the work of either. I could wish that Lady Barlow had given half a dozen pages in this first appendix to quotations from "The Botanic Garden" and from the "Zoonomia". The sonorous lines could be annotated from Buffon or Lucretius, lest the reader forget that Erasmus as an eighteenth century philosophe was expressing his appreciation of an old and richly poetic idea and not assembling the evidence for an inductive proposition. It would be apparent that Erasmus was not trying to do what his grandson later did, and this not from any lack of understanding of the proper procedure of the natural sciences.

I have, for myself, no doubt that Charles would never have undertaken the large task of marshalling the evidence for "descent with modification", which had indeed become much more impressive since Erasmus's time, without having hit upon a truly naturalistic explanation. Speculation, indeed, has an important part to play in inductive reasoning, but speculation supported by a theory which both Cuvier and Lyell had been forced to reject was to Charles Darwin a major obstacle.

\section{R. A. FISHER}

\section{FOOD AND POPULATION}

The Grassland and Fodder Resources of India By R. O. Whyte. (Scientific Monograph No. 22.) Pp. $v+437+50$ plates. (New Delhi : Indian Council of Agricultural Research, 1957.) Rs. 16; 36s.; 5 dollars.

T has been realized for many years that the grazing and fodder resources of India are inadequate to meet the needs of the livestock population and through them the nutritional requirements of the Indian people. This volume, published by the Indian Council of Agricultural Research, reviews our present knowledge of the extent and use of these resources. The author, who is agronomist with the Food and Agriculture Organization of the United Nations, has worked in close collaboration with Indian grassland specialists for the past five years.

In India, most of the livestock is kept in the villages, and although the working animals and buffaloes are hand-fed to some extent, the cows and young stock suffer severely from malnutrition. The village grasslands are heavily over-stocked, and although they can be regenerated by controlled grazing, even then they can supply keep for only four to five months of the year. The improved herbage does not provide adequate nutrition for high-quality cattle, such as dairy cows, which require supplementary fodder rich in protein. The use of sown leys is precluded in most areas by the large and increasing human population, all the cultivable land being of necessity devoted to food and cash crops with a few annual fodder crops.

The author suggests that the most effective increase in livestock production can be obtained by controlled management of the village grasslands, based on a knowledge of their position in the ecological succession to forest, and supplemented by the conservation of fodder for the dry season, and the use of annual leguminous fodder crops.

In practice, however, these recommendations raise serious religious and social difficulties. The optimum carrying capacity of most village grasslands is far lower than the present livestock population, but the strong religious objection to killing old and surplus cattle makes the necessary reduction in numbers rather improbable in the near future. Furthermore, the small size and fragmented nature of the holdings prevent adequate provision of supplementary fodder. To maintain a family and their necessary animals requires over five acres of irrigated land, and considerably more of dryland, yet over most of India 60 per cent of the holdings are less than five acres. 